\title{
Effect of Fly Ash and Carbon Reinforcement on Dry Sliding Wear Behaviour of Red Mud
}

\author{
Harekrushna Sutar, ${ }^{1,2,3}$ Debashis Roy, ${ }^{2}$ and Subash Chandra Mishra ${ }^{3}$ \\ ${ }^{1}$ Chemical Engineering Department, Indira Gandhi Institute of Technology, Sarang, Odisha 759146, India \\ ${ }^{2}$ Chemical Engineering Department, Jadavpur University, Kolkata, West Bengal 700032, India \\ ${ }^{3}$ Metallurgical and Materials Engineering Department, National Institute of Technology, Rourkela 769008, India
}

Correspondence should be addressed to Harekrushna Sutar; h.k.sutar@gmail.com

Received 24 May 2015; Accepted 17 August 2015

Academic Editor: Joseph M. Deitzel

Copyright (C) 2015 Harekrushna Sutar et al. This is an open access article distributed under the Creative Commons Attribution License, which permits unrestricted use, distribution, and reproduction in any medium, provided the original work is properly cited.

\begin{abstract}
This paper explains the sliding wear performance of red mud, fly ash, and carbon composite coating on mild steel. The complex mixture of red mud, fly ash, and carbon is plasma sprayed at $9 \mathrm{~kW}$ operating power level. The coatings are examined to study the coating morphology, XRD phase transformation, wear rate, and wear morphology. Wear rate (in terms of cumulative mass loss) with sliding time has been demonstrated in the study. At first pure red mud is plasma coated to observe the coating characteristics and then compounded with $20 \%$ carbon, $30 \%$ carbon, and $20 \%$ carbon $+30 \%$ fly ash, separately by weight and sliding wear test conducted using pin on disc wear tester. The trial was performed at fixed track diameter of $100 \mathrm{~mm}$ and at sliding speed of $100 \mathrm{rpm}$ $(0.523 \mathrm{~m} / \mathrm{s})$ at a load of $30 \mathrm{~N}$. The results are compared. Declined cumulative mass loss by inclusion of fly ash and carbon is seen. This might be due to augmented interfacial tension and dense film build-up at boundary layer.
\end{abstract}

\section{Introduction}

In the present scenario coating technologies manifest a promising momentum for emerging materials. Wear resistive coatings are claimed to be better tribological applications. Surface modification by improving wear resistance is most widely adopted by plasma spraying technique, which could affirm a great versatility and its application to a wide spectrum of materials. Wear resistive coatings can protect against different wear mediums like abrasive, adhesive, and corrosive. Some common wear resistive coating materials are nickel, iron, cobalt and molybdenum based alloys, carbides of ceramic, and tungsten $[1,2]$. Friction and dry sliding wear behavior of red mud filled banana fibre reinforced unsaturated polyester composites using Taguchi approach reported in [3]. Evaluation and characterization of plasma sprayed $\mathrm{Cu}$ slag-Al composite coatings on metal substrates have been outlined [4]. In retrospection, literatures were made available regarding the wear behaviour of WC with $12 \%$ Co coatings produced by Air Plasma Spraying method at different standoff distances [5].
Examinations on the basis of the wear behaviour of Mo and $\mathrm{Mo}+\mathrm{NiCrBSi}$ thermally sprayed coatings being performed for the application as next generation ring face coatings [6]. Plasma sprayed ceramic coatings portrayed favorable tribological performance at high temperatures [7], showed high wear resistance [8], and were easy to be lubricated owing to the oil storage in pores of coatings [9]. But it is needful to say that plasma sprayed ceramic coatings exhibit some failure mechanisms during sliding such as plastic deformation, brittle fracture, and polish effects [10], which in turn demands a few additives, which could reduce the friction and wear of plasma sprayed ceramic coatings [11]. Several factors may influence the tribological behaviour of a coated surface ramified such as the geometry of the contact including macrogeometry and macrotopography of the surfaces; the material characteristics; basic mechanical properties and the microstructure; and finally the operating parameters controlling the coating deposition [12].

Red mud as an industrial waste material is considered to be the material of choice for coating applications. It is necessary to mention here that red mud in present decade 


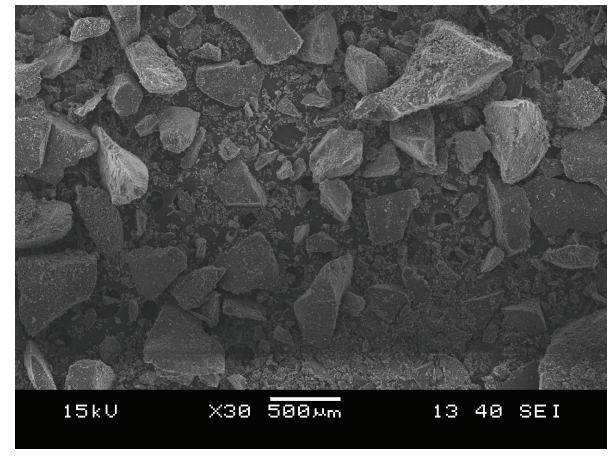

(a)

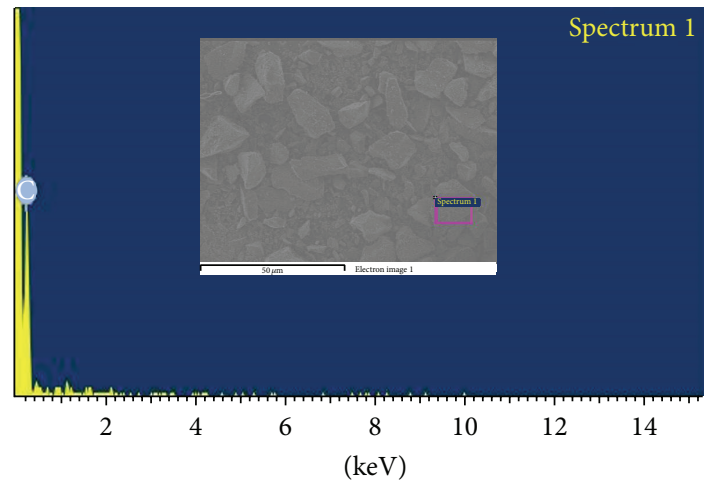

Full scale 79 cts cursor: 0.000

(b)

FIGURE 1: (a) SEM and (b) EDS analysis of activated carbon.

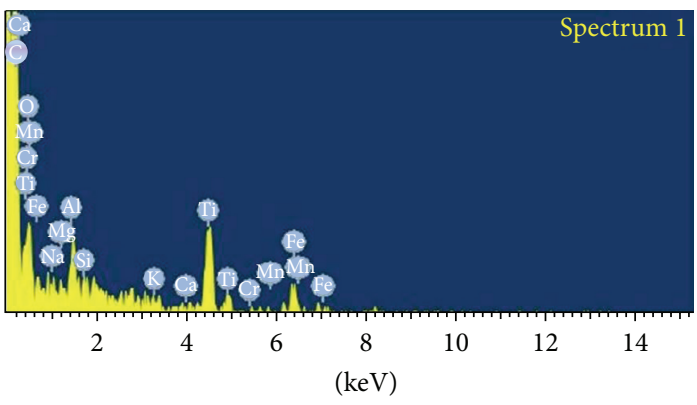

Full scale 79 cts cursor: 0.000

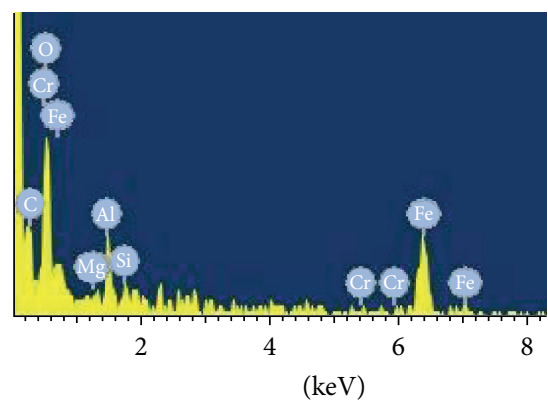

Full scale 79 cts cursor: 0.000

(b)

Figure 2: EDS analysis of (a) RM $+20 \% \mathrm{C}$ and (b) RM $+20 \% \mathrm{C}+30 \%$ FA powder.

should be considered as alternative wealth for replacing some conventional expensive coating materials. Utilization of red mud and its implications are made available in the literature [13] in great detail. Few results on the basis of wear behaviour of red mud were being reported by some researchers. In addition to the above, morphology and solid particle erosion wear behaviour of red mud and fly ash composite were being available in the literature [14]. Dry sliding wear behaviour of rice husk and red mud filled epoxy composites using ANN is described [15]. An outline for resources, utilization, and processes of red mud in India is reviewed [16]. Data pertaining to dry sliding wear behaviour of fly ash and carbon added red mud composite coatings are not available in the literature and need to be addressed. Tribological studies on red mud reinforced aluminium metal matrix composites are disclosed [17]. Friction and wear behaviour of plasma sprayed fly ash added red mud coatings have been analysed [18].

\section{Experimental}

2.1. Raw Materials for Coating. The coating powder was formulated considering the raw materials as red mud, fly ash, and carbon. At incipient pure red mud is plasma
TABle 1: Powder composite.

\begin{tabular}{lcc}
\hline Sl. Number & Material & Composition by weight \% \\
\hline 1 & Red Mud (RM) & 100 \\
2 & RM + Carbon (C) & $80+20$ \\
3 & RM + C & $70+30$ \\
4 & RM + C + Fly Ash (FA) & $50+20+30$ \\
\hline
\end{tabular}

coated. Then a powder mixture made up of red mud and different percentage of fly ash and carbon was being prepared separately. Table 1 shows the detailed composition of the powder composite.

To perceive the significance of activated carbon SEM and EDS analysis images have been reported in Figure 1. To recognize the elements in the composite powder of $\mathrm{RM}+20 \%$ $\mathrm{C}$ and $\mathrm{RM}+20 \% \mathrm{C}+30 \% \mathrm{FA}$ an EDS analysis report has been divulged in Figure 2. A SEM (JEOL; JSM 6480 LV) has been implemented to survey the report.

The primary raw material as red mud was collected in powder form from National Aluminium Company, located at Damanjodi in the state of Odisha, India. The as-received powder was sieved to obtain particles in the required size 


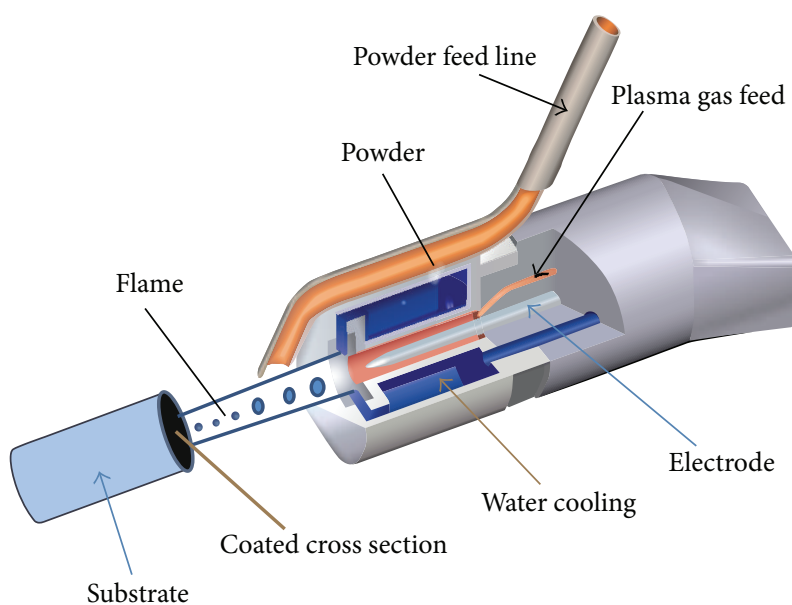

FIgURE 3: Compact outline of APS.

range of $80-100 \mu \mathrm{m}$. Raw fly ash was collected from the captive power plant of Rourkela steel plant, India, and sieved to maintain the same size range as that of red mud powder. The charcoal is used for the source of carbon. The specific size ranges of powder are mixed in a $\mathrm{V}$-shaped blender for uniformity of composite.

2.2. Build-up of Substrate. The mild steel rod is chopped to $l=$ $42 \mathrm{~mm}$ and $\varnothing=15 \mathrm{~mm}$ each. Grit blasting of the specimens was conducted from one side cross section at a pressure of $4 \mathrm{~kg} / \mathrm{cm}^{2}$ using alumina grits of grit size 80 . The dead lock distance in the shot blasting was in between $120-150 \mathrm{~mm}$. The mean roughness of the cross sections was found to be $5.8 \mu \mathrm{m}$. Hereafter the sample pieces are scrubbed in an ultrasonic cleaning unit followed by immediate plasma spraying.

2.3. Substrate Coating. Coating of the substrate was done using conventional atmospheric plasma spraying (APS) unit available at surface engineering department of IMMT, Bhubaneswar, Odisha, India. All the mild steel specimens were coated from one cross section at $9 \mathrm{~kW}$ operating power level by controlling the voltage and current input to the arc. The powder feed rate was maintained to be constant at $15 \mathrm{gm} / \mathrm{min}$ by using a turntable type volumetric powder feeder. Plasma generation implemented by purging argon as primary and nitrogen as secondary gas agent. Spraying was done at an angle of $90^{\circ}$ by maintaining the powder feeding as external to the gun. A compact outline of APS is reflected in Figure 3.

2.4. Wear Test Setup. The wear test was conducted using a pin on disc appliance allotted by MAGNUM Engineers, Bangalore, India. A comprehensive outline of the setup is materialized in Figure 4. The concerned machine was used to evaluate the wear behaviour of the coatings against hardened ground steel disc (En-32) having hardness of $65 \mathrm{HRC}$ and surface roughness of $0.5 \mu \mathrm{m}$. The machine is so fabricated that it can examine wear rate both at lubricated and unlubricated conditions. A DC motor is implicated for rotating the disc with range of speed from 0 to $250 \mathrm{rpm}$ with wear track

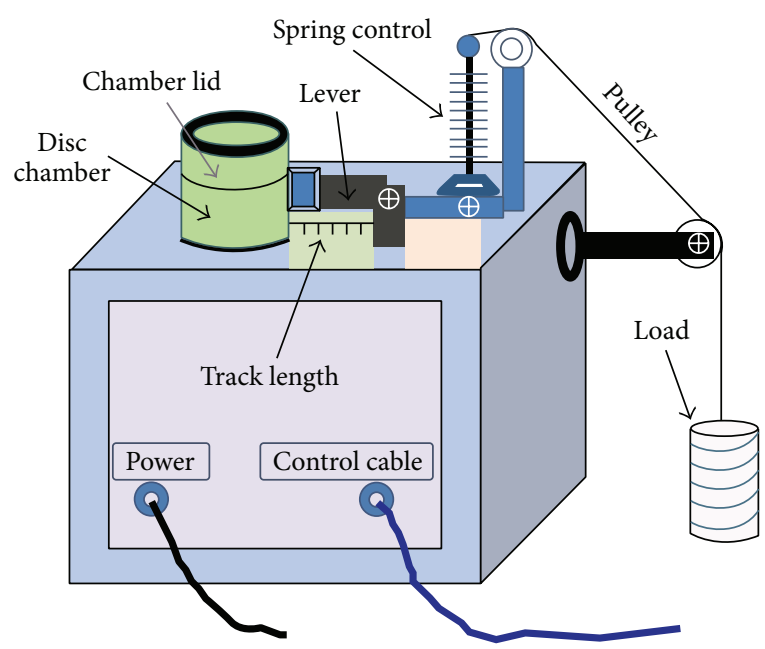

FIGURE 4: A comprehensive outline of pin on disc apparatus.

diameter $0-150 \mathrm{~mm}$, yielding a sliding speed of $0-15 \mathrm{~m} / \mathrm{s}$. Dead weight was applied on the pin by means of pulley and string arrangement. The system has a maximum loading capacity of $400 \mathrm{~N}$. The device is fabricated to keep the pin specimen stationary and perpendicular to disc, while the circular disc spinning anticlockwise as normal practice.

\section{Result Analysis and Discussion}

3.1. Coating Morphology Survey. Interparticle bonding of the sprayed powders and coating surface adherence plays an important role to characterize the coating morphology [19]. Even though all the coating is performed at $9 \mathrm{~kW}$ operating power level, it is noteworthy to analyse the coating morphology for all coating types used in the present study and reported in Figure 5. In case of pure red mud coating, the snapshot signifies (Figure 5(a)) nonuniform distribution of bigger globular particles. Improper melting and cavitations are visible. For RM $+20 \%$ C the coating morphology reveals more spotted cavitations which may be originated at the time of solidification and nonuniformity of surface. As the carbon content increased $(\mathrm{RM}+30 \% \mathrm{C})$ the uniformity of the surface has been improved but still large-size cavitations are spotted with few semimolten particles. It is compelling to discuss the results for $\mathrm{RM}+20 \% \mathrm{C}+30 \%$ FA coating; which is contrary to the past. Figure 5(d) reveals the outcome. Very small scale cavitations are marked with most of the regions' uniform and splat. This might be resulting from additional amount of Si, $\mathrm{Al}$, and Fe content coming from fly ash.

3.2. XRD Phase Analysis of Raw Material and Coatings. To discover the different phases occurring in the precursor powder and its coating; a Philips X-Ray Diffractometer is incorporated. Figure 6 shows the XRD of activated carbon powder. The XRD result for red mud powder is shown in Figure 7. The major phases of red mud powder such as silicon dioxide $\left(\mathrm{SiO}_{2}\right)$, iron oxide $\left(\mathrm{Fe}_{2} \mathrm{O}_{3}\right)$, titanium dioxide $\left(\mathrm{TiO}_{2}\right)$, and minor phases like Vanadium Oxide $\left(\mathrm{VO}_{2}\right)$ were seen.

The XRD of $\mathrm{RM}+20 \% \mathrm{C}$ powder primarily contains phases of sodium sulfite $\left(\mathrm{Na}_{2} \mathrm{SO}_{3}\right)$, iron oxide $\left(\mathrm{Fe}_{2} \mathrm{O}_{3}\right)$, and 


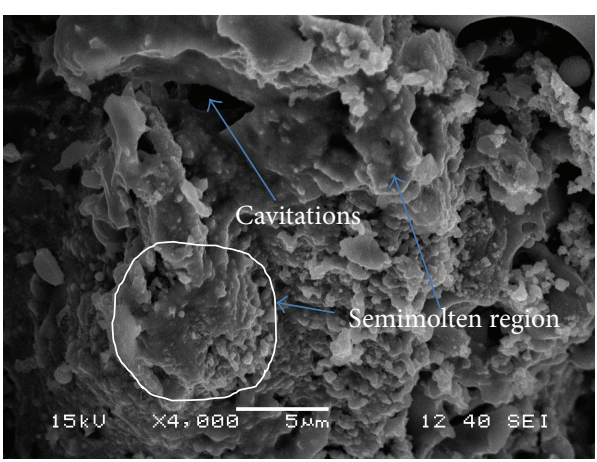

(a)

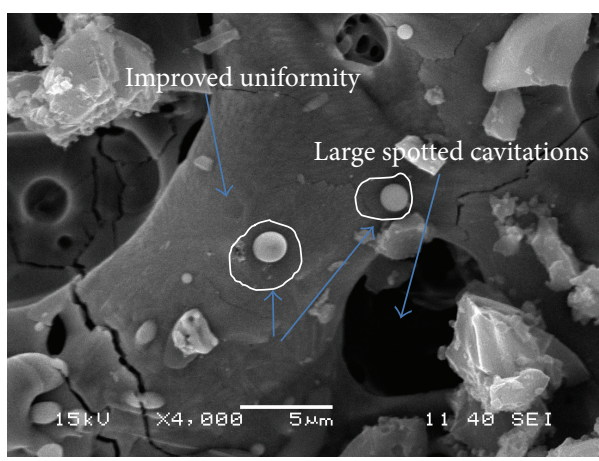

(c)

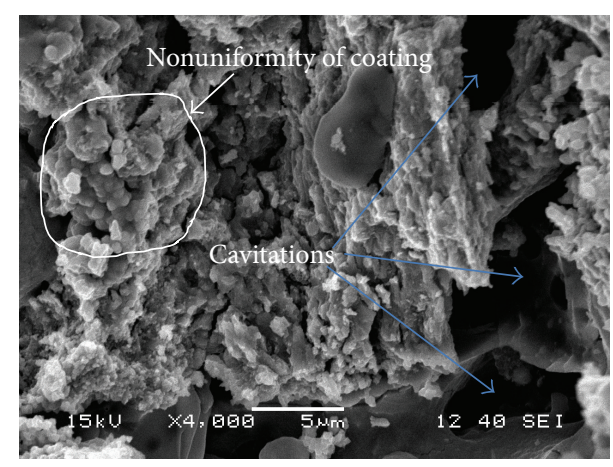

(b)

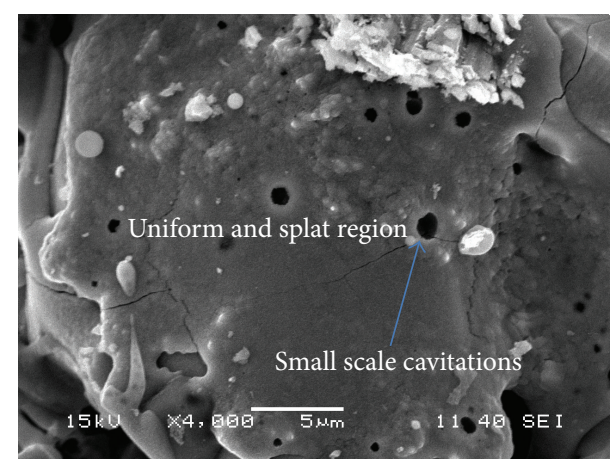

(d)

FIGURE 5: Coating morphology: (a) RM, (b) RM + 20\% C, (c) RM + 30\% C, and (d) RM + 20\% C + 30\% FA.

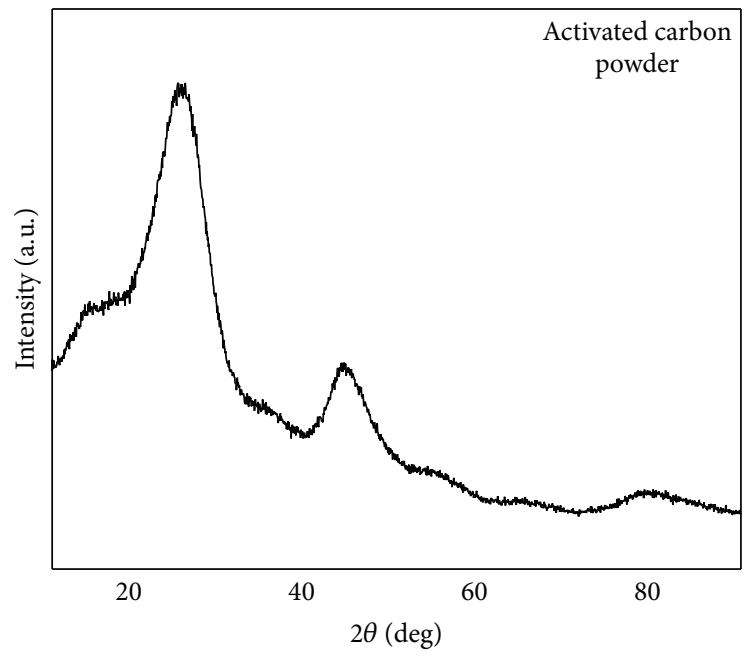

FIGURE 6: XRD of activated carbon.

aluminium iron oxide $\left(\mathrm{AlFeO}_{3}\right)$. After plasma coating there is a major phase change to fayalite $\left(\mathrm{Fe}_{2} \mathrm{SiO}_{4}\right)$ and dolomite as visible in Figure 8.

Figure 9 shows the XRD diffractogram of (a) RM + 20\% C $+30 \%$ FA powder and (b) RM $+20 \% \mathrm{C}+30 \% \mathrm{FA}$ coating. The chief XRD peaks for the powder are silicon dioxide $\left(\mathrm{SiO}_{2}\right)$, hematite $\left(\mathrm{Fe}_{2} \mathrm{O}_{3}\right)$, limestone $\left(\mathrm{CaCO}_{3}\right)$, and titanium dioxide $\left(\mathrm{TiO}_{2}\right)$. After successful plasma coating the major phases reconstructed to manganese aluminate $\left(\mathrm{MnAl}_{2} \mathrm{O}_{4}\right)$.

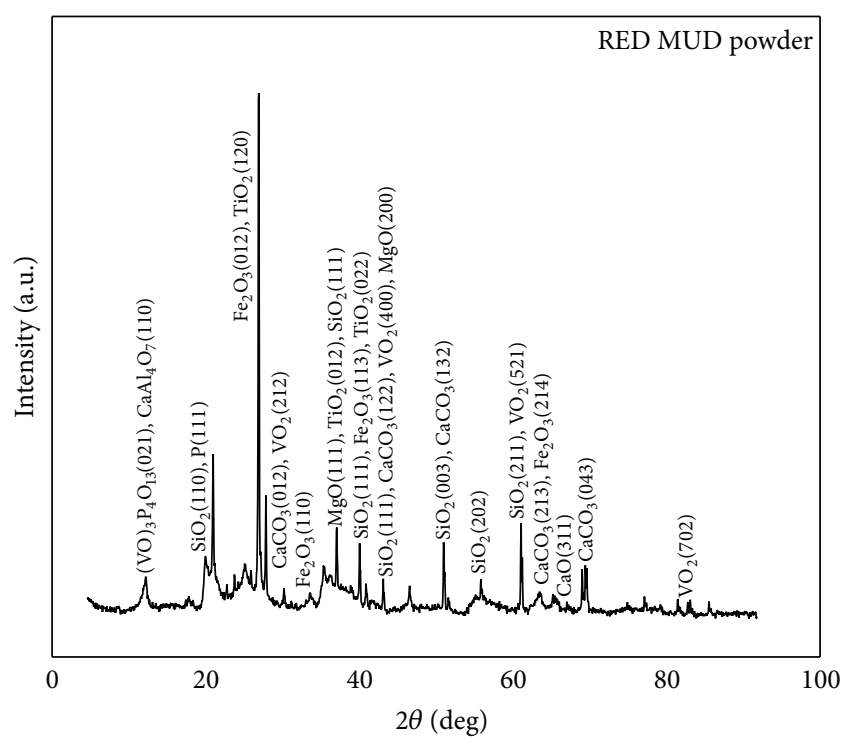

FIGURE 7: XRD of red mud.

3.3. Design of Wear Rate. The wear tests were carried out as per ASTM G-99 standard under unlubricated condition at standard atmospheric temperature and pressure. Sliding wear test was conducted at normal load of $30 \mathrm{~N}$ at a rotational speed of $100 \mathrm{rpm}$. The track diameter was retained at $100 \mathrm{~mm}$. The test was conducted for a total duration of 54 minutes for each coating type. Total duration of sliding was divided 


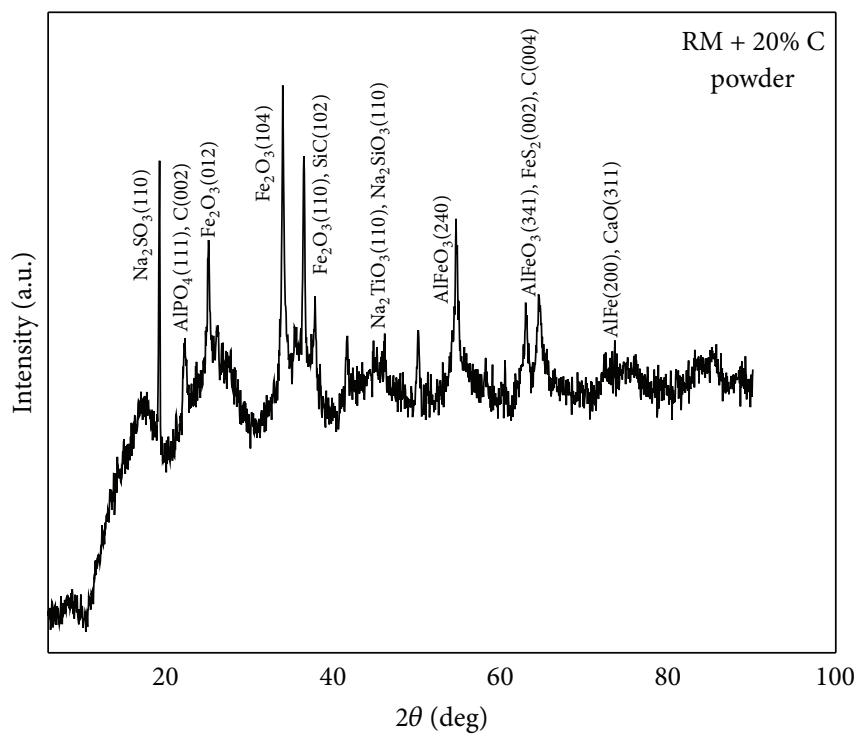

(a)

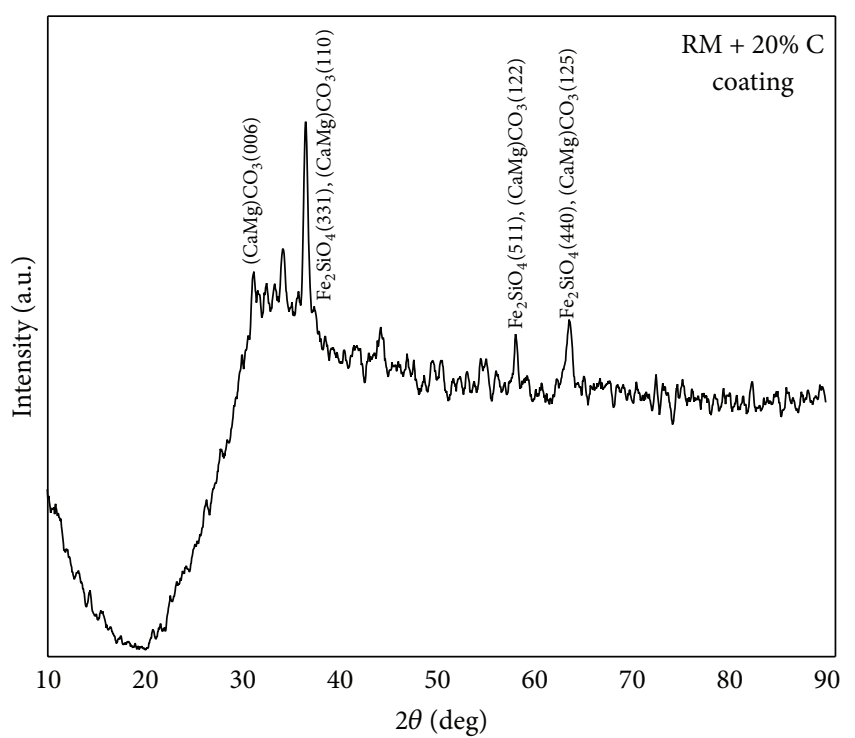

(b)

Figure 8: XRD of (a) RM $+20 \%$ C powder and (b) RM $+20 \%$ C coating.

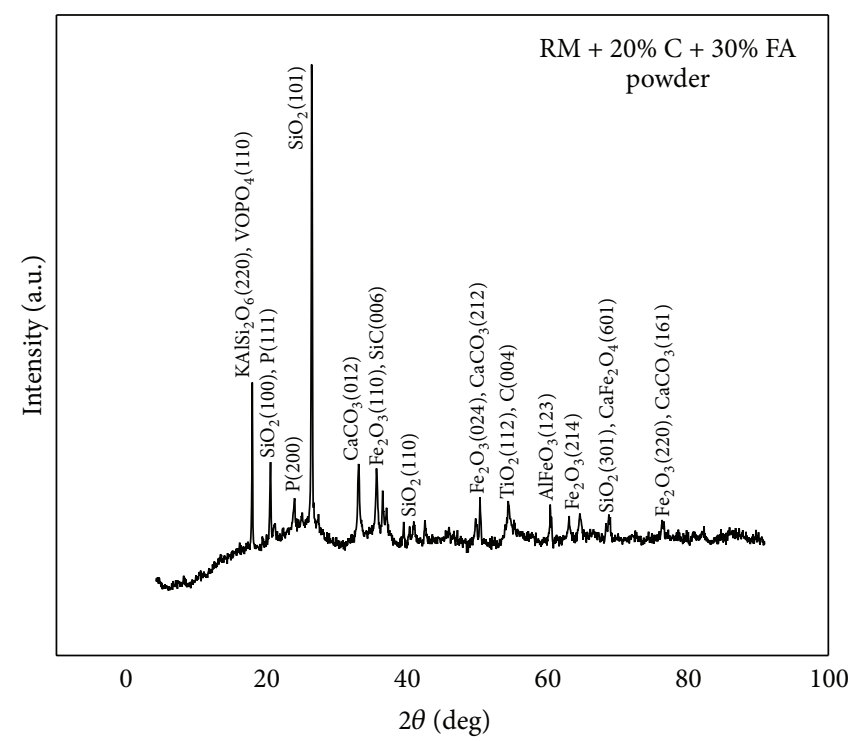

(a)

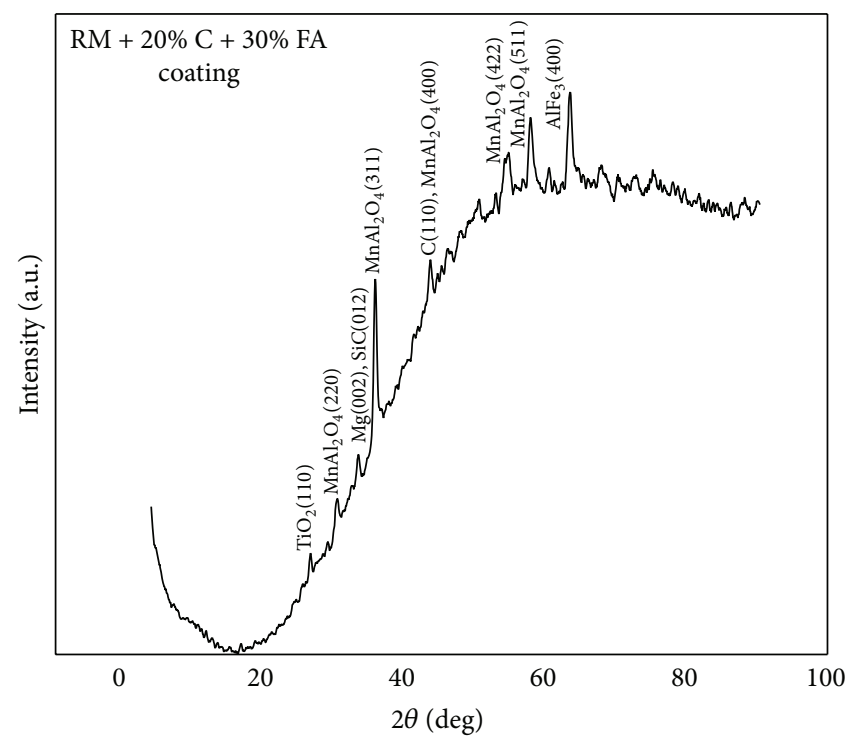

(b)

Figure 9: $\mathrm{XRD}$ of (a) RM $+20 \% \mathrm{C}+30 \% \mathrm{FA}$ powder and (b) $\mathrm{RM}+20 \% \mathrm{C}+30 \% \mathrm{FA}$ coating.

into 18 intervals with 3-minute time gap each. Mass loss in each intervening time was added and expressed as cumulative mass loss. The behaviour of cumulative mass loss with sliding time is expressed in Figure 10 for all coating types.

It is observed that the cumulative mass loss is always more for pure red mud coating for all time intervals. As the carbon content in the red mud increases (addition of carbon by $20 \%$ and $30 \%$ by weight), the cumulative mass loss declines. Figure 10 signifies a minimum value of cumulative mass loss for $\mathrm{RM}+20 \% \mathrm{C}+30 \% \mathrm{FA}$ coating. This might be due to addition of carbon and fly ash to red mud resulting in improved bond strength and interfacial tension of the coating layer to the substrate border line by forming a denser film. This reveals the potential reuse of fly ash as reinforcing agent for coating material. Wear morphology for all coatings are exposed in Figure 11 aided by SEM after 30-minute sliding. The wear mechanism changes with time due to continuous sliding and rubbing action in the interlayer, impacting the surface roughness of coatings. It is believed that wear takes place only by abrasion and adhesion mechanism due to existence of continuous shear stress in between hard particles of the two surfaces in contact. 


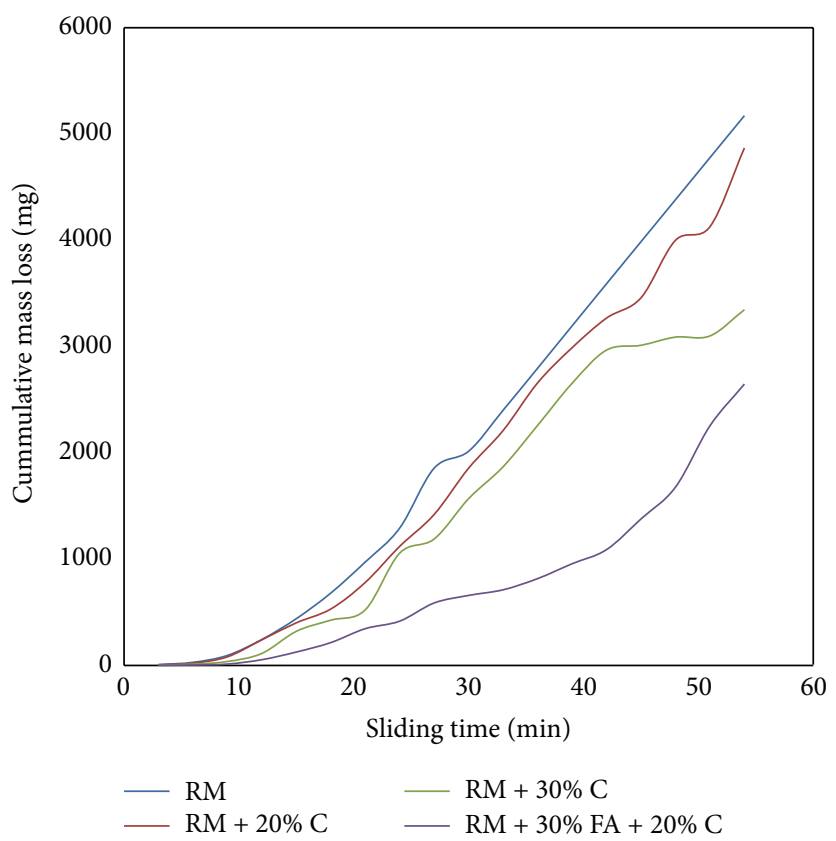

FIGURE 10: Wear behaviour plot.

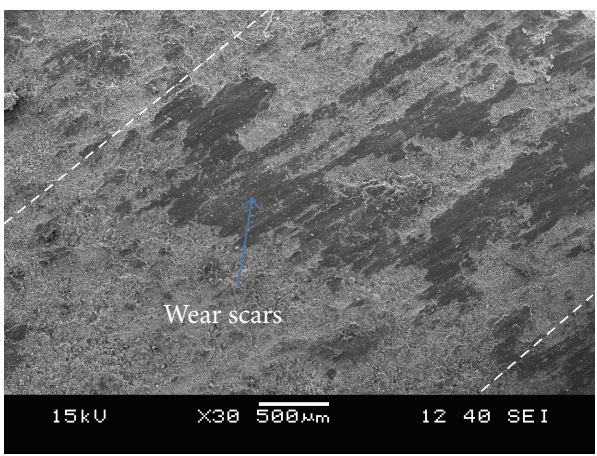

(a)

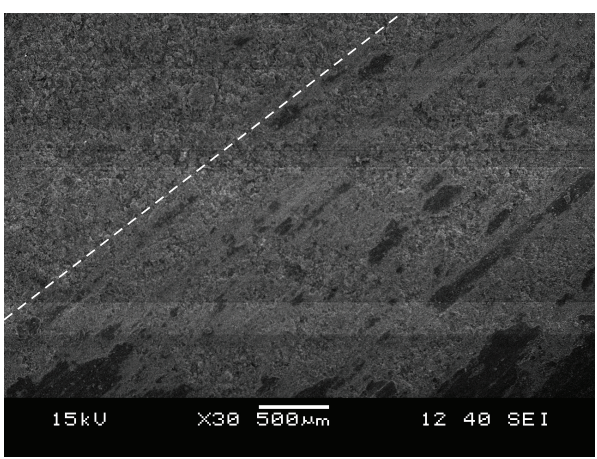

(c)

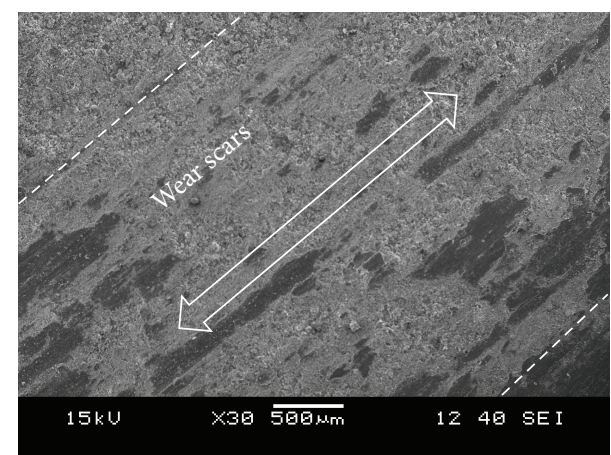

(b)

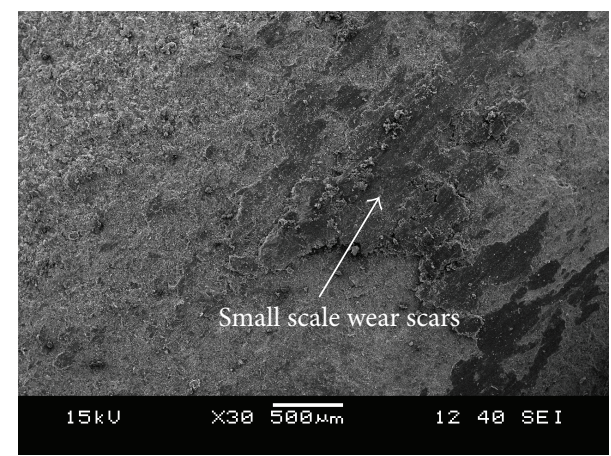

(d)

FIgURE 11: Wear morphology at 30-minute time interval: (a) RM, (b) RM + 20 C, (c) RM + 30\% C, and (d) RM + 20\% C + 30\% FA.

\section{Conclusion}

The above work attempted to study the dry sliding wear behaviour of red mud compounded with a limited extent of reinforcement of carbon and fly ash. A further study can be conducted to expand the limitations. It is obvious from this research that carbon and fly ash enhances the coating property of red mud by amending the surface physical properties. The work strongly attracts tribologists to investigate the response towards corrosion wear of prevailing coatings. 
An optimization technique may be implemented to find the optimum percentage of carbon and fly ash. High temperature application for thermal security may be evaluated at suitable operating conditions. Further heat treatment of the coatings may be employed to disclose the acceptable demands.

\section{Conflict of Interests}

The authors have declared that no competing interests exist.

\section{References}

[1] B. A. Kushner and E. R. Novinski, "Thermal spray coating," in Friction, Lubrication and Wear Technology, vol. 18, pp. 829-833, ASM Hand Book, 1992.

[2] P. Crook, Friction and Wear of Hardfacing Alloys, vol. 18 of ASM Handbook, ASTM International, 1992.

[3] V. A. Prabu, V. Manikandan, and M. Uthayakumar, "Friction and dry sliding wear behavior of red mud filled banana fibre reinforced unsaturated polyester composites using Taguchi approach," Materials Physics and Mechanics, vol. 15, no. 1, pp. 34-45, 2012.

[4] S. Mantry, B. B. Jha, and A. Satapathy, "Evaluation and characterization of plasma sprayed cu slag-al composite coatings on metal substrates," Journal of Coatings, vol. 2013, Article ID 842865, 7 pages, 2013.

[5] M. Afzal, M. Ajmal, and A. Nusair Khan, "Wear behavior of WC-12\%co coatings produced by air plasma spraying at different standoff distances," Tribology Transactions, vol. 57, no. 1, pp. 94-103, 2013.

[6] S. F. Wayne, S. Sampath, and V. Anand, "Wear mechanisms in thermally sprayed mo-based coatings," Tribology Transactions, vol. 37, no. 3, pp. 636-640, 1994.

[7] Y. Wang, Y. Jin, and S. Wen, "The analysis of the friction and wear mechanisms of plasma-sprayed ceramic coatings at $450^{\circ}$ C," Wear, vol. 128, no. 3, pp. 265-276, 1988.

[8] Y. Wang, Y. Jin, and S. Wen, "The analysis of the chemical structure and properties of ceramic surface films in friction using SEM, AES and Micro-region X-ray diffraction," Wear, vol. 128, pp. 277-290, 1998.

[9] W. Yinglong, J. Yuansheng, and W. Shizhu, "The inspection of the sliding surface and subsurface of plasma-sprayed ceramic coatings using scanning acoustic microscopy," Wear, vol. 134, no. 2, pp. 399-411, 1989.

[10] R. Vijande-Diaz, J. Belzunce, E. Fernandez, A. Rincon, and M. C. Pérez, "Wear and microstructure in fine ceramic coatings," Wear, vol. 148, no. 2, pp. 221-233, 1991.

[11] J. Wei and Q. Xue, "Effects of additives on friction and wear behaviour of Cr coatings," Wear, vol. 160, pp. 61-65, 1993.

[12] K. Holmberg, A. Matthews, and H. Ronkainen, "Coatings tribology-contact mechanisms and surface design," Tribology International, vol. 31, no. 1-3, pp. 107-120, 1998.

[13] H. Sutar, S. C. Mishra, S. K. Sahoo, A. P. Chakraverty, and H. S. Maharana, "Progress of red mud utilization: an overview," American Chemical Science Journal, vol. 4, no. 3, pp. 255-279, 2014.

[14] H. Sutar, S. C. Mishra, S. K. Sahoo, A. Satapathy, and V. Kumar, "Morphology and solid particle erosion wear behavior of red mud composite coatings," Natural Science, vol. 4, no. 11, pp. 832$838,2012$.
[15] A. Rout and A. Satapathy, "Analysis of dry sliding wear behaviour of rice husk filled epoxy composites using design of experiment and ANN," Procedia Engineering, vol. 38, pp. 12181232, 2012.

[16] S. Samal, A. K. Ray, and A. Bandopadhyay, "Proposal for resources, utilization and processes of red mud in India: a review," International Journal of Mineral Processing, vol. 118, pp. 43-55, 2012.

[17] S. Rajesh, S. Rajakarunakaran, R. Suthakarapandian, and P. Pitchipoo, "MOORA-based tribological studies on red mud reinforced aluminum metal matrix composites," Advances in Tribology, vol. 2013, Article ID 213914, 8 pages, 2013.

[18] H. Sutar, D. Roy, S. Mishra, A. Chakraverty, and H. Maharana, "Friction and wear behaviour of plasma sprayed fly ash added red mud coatings," Physical Science International Journal, vol. 5, no. 1, pp. 61-73, 2015.

[19] A. Satapathy, Thermal spray coating of red mud on metals [Ph.D. thesis], National Institute of Technology, Rourkela, India, 2005. 

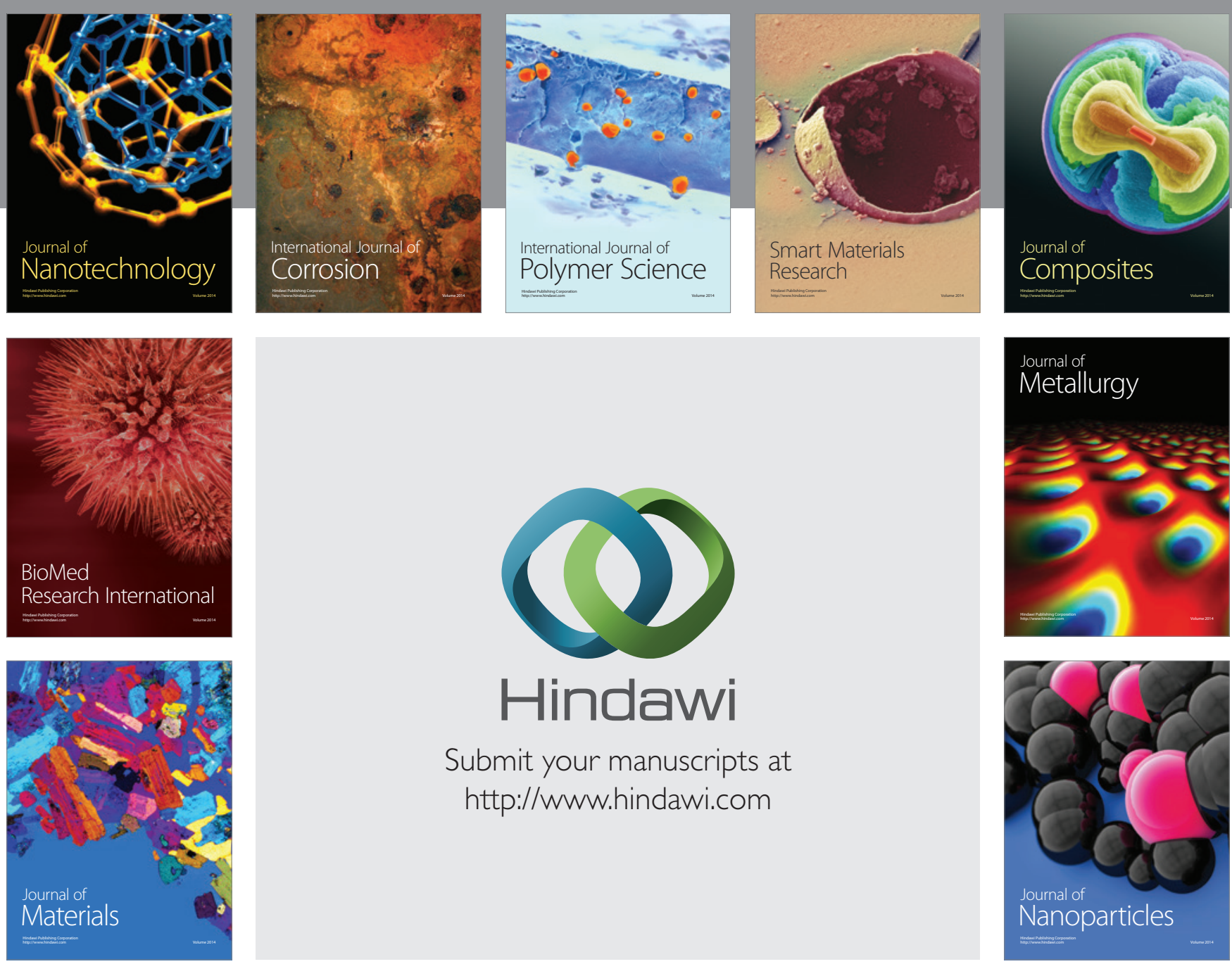

Submit your manuscripts at http://www.hindawi.com
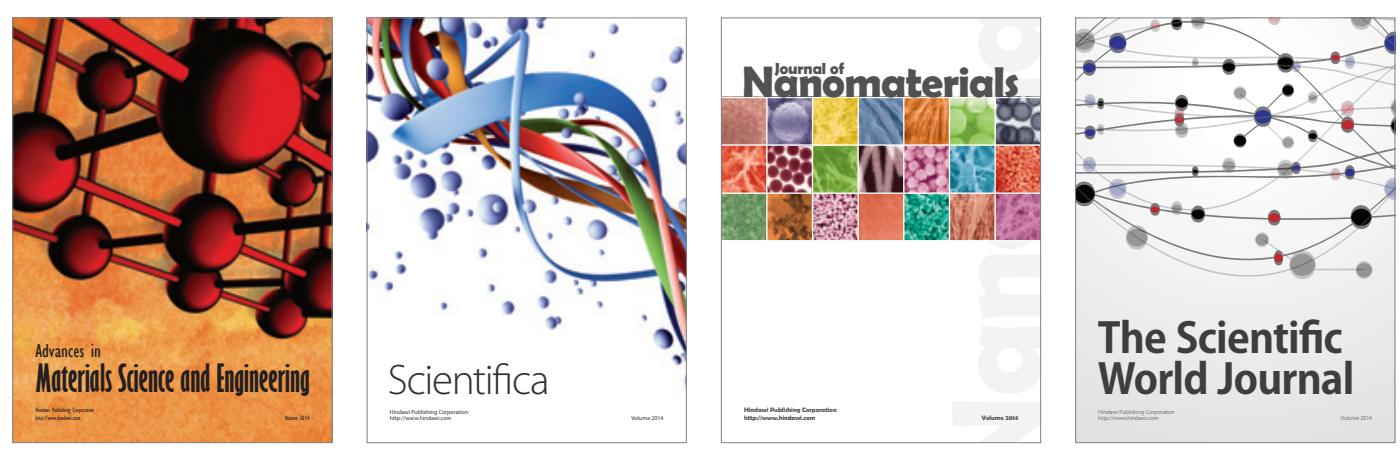

\section{The Scientific World Journal}
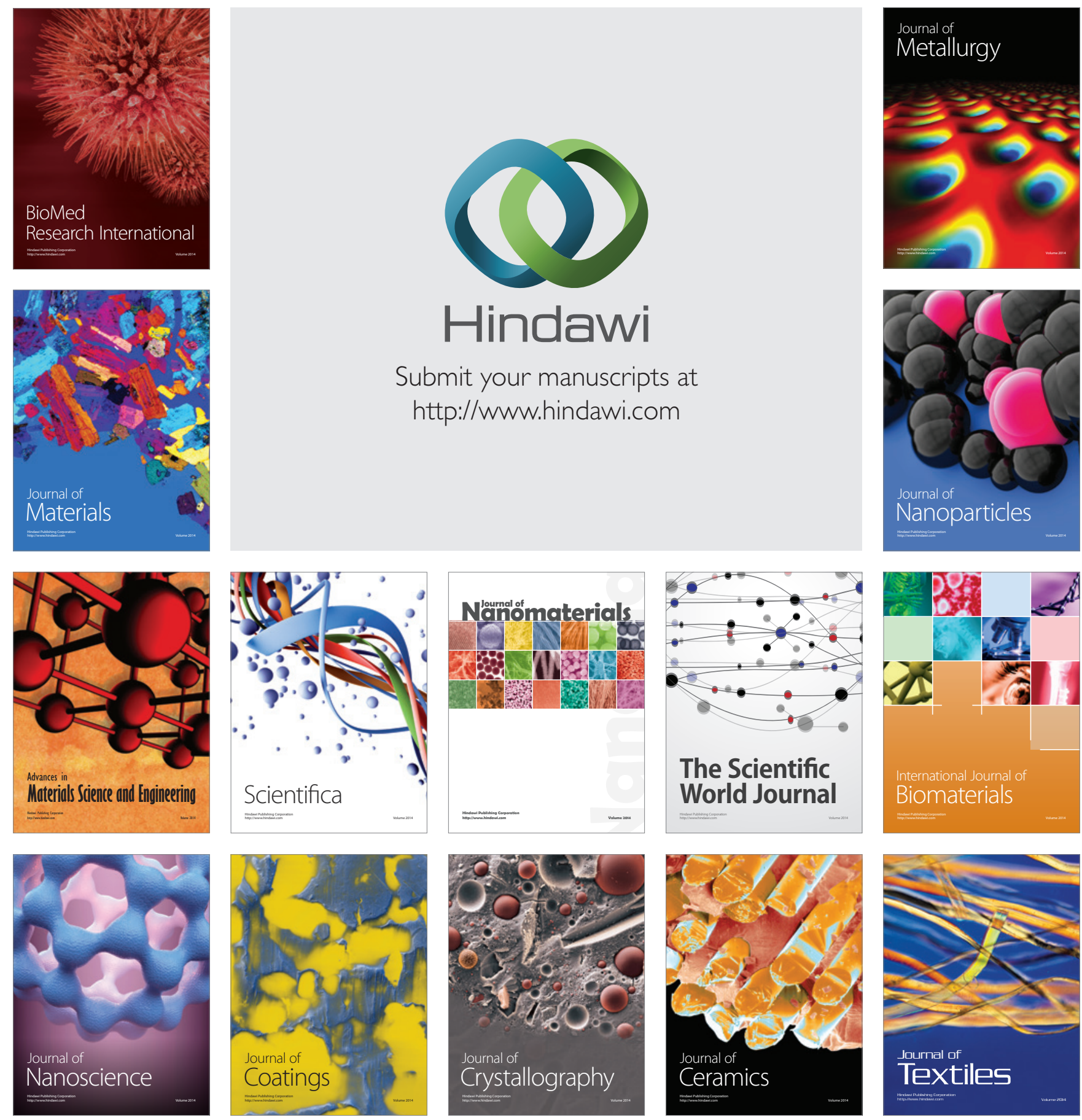